\title{
1,5-Anhydro-D-fructose, a New Material for Modification of Amino Groups as Demonstrated Using Amino Acid and Proteins
}

\author{
Kazuhiro Yoshinaga, Mami Fujisue, ${ }^{1}$ Jun-ichi Abe, ${ }^{2, *}$ \\ Yasuhito Takeda ${ }^{2}$ and Susumu Hizukuri ${ }^{3}$ \\ The United Graduate School of Agricultural Sciences, Kagoshima University \\ (1-21-24, Korimoto, Kagoshima 890-0065, Japan) \\ ${ }^{1}$ Nihondenpun Kogyo Co. \\ (3-20, Nanei, Kagoshima 891-0196, Japan) \\ ${ }^{2}$ Department of Biochemical Science and Technology, Faculty of Agriculture, Kagoshima University \\ (1-21-24, Korimoto, Kagoshima 890-0065, Japan) \\ ${ }^{3}$ Faculty of Home Economics, Kobe Women's University \\ (2-1, Aoyama, Higashisuma, Kobe 654-8585, Japan)
}

\begin{abstract}
1,5-Anhydro-D-fructose (1,5-anhydro-D-arabino-hexo-2-ulose, 1,5-AF) reacted well with the amino group and seemed to be useful as a reagent for modification of the amino compounds. The rate of browning of 1,5-AF by reaction with glycine was higher than those of glucose and xylose at $50^{\circ} \mathrm{C}$ and $\mathrm{pH}$ 7.5. Forty-five percent of the amino group of glycine was modified by the incubation of a lyophilized mixture of $1,5-\mathrm{AF}$ and glycine at $30^{\circ} \mathrm{C}$ for $48 \mathrm{~h}$, whereas the degree of modification by glucose was less than $5 \%$. This modification was applied to lysozyme. A mass spectrum indicated that the sugar moiety was incorporated into the lysozyme. The optimum $\mathrm{pH}$ values of the modified and unmodified lysozyme on glycolchitin were $\mathrm{pH} 4.5$ and 5.0, respectively. On the other hand, the optimum $\mathrm{pH}$ of the modified enzyme on freeze-dried cells of Micrococcus lysodeikticus shifted from pH 7.8 to 6.0. Wheat proteins, gliadin and glutenin, were also modified. The modified gliadin had higher emulsification ability and solubility than the unmodified ones.
\end{abstract}

$1,5-\mathrm{AF}$ is a sugar that was isolated from several fungi $^{1)}$ and an edible seaweed ${ }^{2)}$ as an intermediate of the biosynthetic pathway for microthecin, and now the sugar is considered to be distributed widely among organisms, including animals. ${ }^{3)}$ The sugar is prepared conveniently from $\alpha$-1,4-glucan by the action of $\alpha-1,4$-glucan lyase ${ }^{1,4)}$ and regarded to be highly reactive, since it has an ethylenic linkage in its molecule. ${ }^{1} \mathrm{Yu}$ et al. have reported that $1,5-\mathrm{AF}$ was a highly reactive sugar. ${ }^{5)}$ We have reported that $1,5-\mathrm{AF}$ has higher antioxidative activity than ascorbic acid does by weight ${ }^{6}$ and reduces cupric and ferric ions even at $35^{\circ} \mathrm{C}$. The latter reactivity allows sensitive and selective determination of $1,5-\mathrm{AF}^{\text {?) }}$

\footnotetext{
* To whom all correspondence should be addressed (J_abe@chem.agri.kagoshima-u.ac.jp).
}

It is well known that the carbonyl group reacts with the amino group (Maillard reaction). The preparation of some conjugates of food proteins and sugars for functional improvement has been reported. For example, the thermal stability and emulsification ability of ovalbumin are improved by modification with glucose 6-phosphate, ${ }^{8)}$ and the modification of lysozyme with glucose-stearic acid monoester enhances its ability to emulsify." The problems in this procedure are a rather high temperature and/or long incubation times needed for the reaction. Since the reactivity of $1,5-\mathrm{AF}$ is higher than of other reducing sugars such as glucose, fructose, and xylose, 1,5-AF may overcome these drawbacks and be more suitable for the production of glycosylated food proteins.

In this study we examined the properties of 1,5$\mathrm{AF}$ as a new modifier of amino groups of an 
amino acid and protein. To begin with, we examined suitable conditions for the conjugation, using glycine as a target. We then modified lysozyme, which is often used as a preservative in the food industry, in expectation of an improvement of the enzymatic nature of lysozyme such as substrate specificity, $\mathrm{pH}$ profile and heat stability. We also modified the major proteins in wheat flour in order to improve the properties of wheat flour. We may be able to expect an increase of water holding capacities and an improvement of textures in breads and noodles by introducing sugar moieties to those proteins.

\section{MATERIALS AND METHODS}

Materials. 1,5-AF was prepared from waxycorn starch by the action of $\alpha$-1,4-glucan lyase. ${ }^{6}$ The purity of the1,5-AF produced was $98.5 \%$ on HPLC (Mitsubishi Chemical Co., MCI Gel CK 08 S). Chicken egg-white lysozyme (crystal grade) was purchased from Sigma. Glycolchitin was prepared from chitin. ${ }^{10}$ The lyophilized cells of $M i$ crococcus lysodeikticus were from Nacalai Tesque Inc. Protein assay reagent was purchased from BioRad Laboratories. Glutenin and gliadin were prepared from wheat flour. ${ }^{11}$ Other chemicals were of reagent grade.

Browning of sugars. The mixture of a sugar $(5 \%, \mathrm{w} / \mathrm{v})$ and glycine $(5 \%, \mathrm{w} / \mathrm{v})$ in $50 \mathrm{~mm}$ phosphate buffer ( $\mathrm{pH} 7.5)$ was incubated at $50^{\circ} \mathrm{C}$, and the resulting brown color was monitored on a spectrophotometer at $420 \mathrm{~nm}$, using a $1 \mathrm{~cm}$ light path.

Modification of amino group. A mixture of glycine or protein and a sugar in $100 \mathrm{~mm}$ phosphate buffer ( $\mathrm{pH} 7.5)$ or the same buffer containing $10 \%$ ethanol (in the case of wheat proteins) was dried under reduced pressure for $12 \mathrm{~h}$ at room temperature, and then incubated over saturated $\mathrm{NaOH}$ (relative humidity of $7.6 \%$ at $30^{\circ} \mathrm{C}$ for $12-$ $48 \mathrm{~h}$ ). The extent of modification was calculated by the determination of a free amino group with trinitrobenzensulfonic acid (TNBS) reagent. ${ }^{12)}$ In the case of wheat proteins, a free amino group was determined by TNBS reagent after the addition of sulfuric acid. ${ }^{13)}$
The molecular weight of the modified or unmodified lysozyme were determined by sodium dodecyl sulfate-polyacrylamide gel electrophoresis (SDS-PAGE) using egg albumin, triosephosphate isomerase and chicken egg-white lysozyme as the molecular markers or time of flight mass spectroscopy (TOF-MS) on Voyager-DE PRO (PE Biosystems).

Assay of lysozyme. The activity of lysozyme on glycolchitin was measured by the method of Yamada et al. ." One unit of activity is defined as the amount of the enzyme that decreases the absorbance of 0.001 at $420 \mathrm{~nm} / \mathrm{min}$, using a light path of $1 \mathrm{~cm}$. Lytic activity of the enzyme was determined as follows: The suspension $\left(2 \mathrm{~mL}, A_{450}\right.$ $=1.0$ ) of $M$. lysodeikticus cells in $50 \mathrm{mM}$ buffers and $25 \mu \mathrm{L}$ of enzyme were incubated at $25^{\circ} \mathrm{C}$ for $20 \mathrm{~min}$. The turbidity of the mixture was measured at $450 \mathrm{~nm}$, using a light path of $1 \mathrm{~cm}$. One unit is defined as the amount of the enzyme that decreases the absorbance of 0.001 at $450 \mathrm{~nm} / \mathrm{min}$.

Heat stability of modified lysozyme. A lysozyme preparation $(50 \mu \mathrm{g} / \mathrm{mL})$ in $50 \mathrm{mM}$ phosphate buffer ( $\mathrm{pH} 5.1$ or 7.8 ) was incubated at $75^{\circ} \mathrm{C}$ for $60 \mathrm{~min}$. The remaining activity was then measured by using the lyophilized cells of M. lysodeikticus as described above.

\section{Assay of emulsification ability and solubility.}

Emulsification ability was determined by the method of Aoki et al. ${ }^{14)}$ Solubility was calculated as follows. Twenty $\mathrm{mg}$ of the protein specimen was suspended in $1 \mathrm{~mL}$ of $10 \mathrm{mM}$ acetate buffer $(\mathrm{pH}$ 6.0) at room temperature for $1 \mathrm{~h}$. Then the protein content of the supernatant was measured with BioRad protein assay reagent after centrifugation at $3000 \times g$ for $10 \mathrm{~min}$.

\section{RESULTS AND DISCUSSION}

\section{Browning reaction.}

The reactivity of 1,5-AF with the amino group was found to be significantly higher than that of glucose or xylose. After incubation of the reaction mixtures of each sugar and glycine at $50^{\circ} \mathrm{C}$ for 80 min, $A_{420}$ of the mixture of $1,5-\mathrm{AF}$ was 1.8 ; that of xylose was 0.1 , no color with glucose (Fig. 1). Xylose has been reported as the sugar that causes 


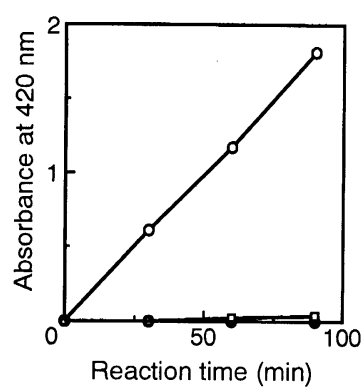

Fig. 1. Browning of mixtures of sugars and glycine at $50^{\circ} \mathrm{C}, \mathrm{pH} 7.5$.

The mixture of a sugar $(5 \%, \mathrm{w} / \mathrm{v})$ and glycine $(5 \%, \mathrm{w} /$ v) in $50 \mathrm{~mm}$ phosphate buffer $(\mathrm{pH} 7.5)$ was incubated at $50^{\circ} \mathrm{C}$. $\bigcirc, 1,5-\mathrm{AF} ; \bigcirc$, glucose; $\square$, xylose.

the largest extent of amino-carbonyl reaction among the known reducing sugars ${ }^{15)}$; thus, 1,5-AF might be the best sugar for this reaction. The Maillard reaction is often used in food processing to bring out the flavor and/or color and to improve the taste of various foods; however, the reaction needs a rather high temperature. The high reactivity property of $1,5-\mathrm{AF}$ prompted us to create a "neoglycoprotein" by the modification of amino groups in some proteins under mild conditions without losing the functional structure and activity of the proteins.

\section{Modification of glycine with 1,5-AF.}

To find the best conditions for modification, we tested a sugar's reaction with glycine under various conditions. Forty-five percent of the amino group was modified with 1,5-AF, and the extent of modification with glucose was less than $5 \%$ (Fig. 2) at the molar ratio of sugar to glycine, $15: 1$ at $30^{\circ} \mathrm{C}$ for $48 \mathrm{~h}$. The modification with 1,5 AF was rapid until $24 \mathrm{~h}$, then the reaction seemed to reach plateau. The reason why the reaction almost ceased after $24 \mathrm{~h}$ still remains to be clarified.

The degree of modification increased with the increase in the reaction tested from 20 to $50^{\circ} \mathrm{C}$ (Fig. 3A). It is noteworthy that the reaction proceeded even at a low temperature of $20^{\circ} \mathrm{C}$; thus, this modification can be applicable for use with materials unstable when heated. The 1,5-AF/glycine ratios of 20 to 30 seemed enough for the more than $40 \%$ of glycosylation when operated at

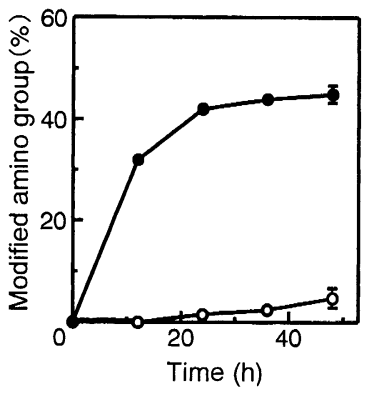

Fig. 2. Modification of glycine with 1,5-AF or glucose.

The mixtures with the molar ratio of sugars to glycine, $15: 1$, were lyophilized and incubated at $30^{\circ} \mathrm{C}$ under $7.6 \%$ relative humidity. $1,5-\mathrm{AF} ; \mathrm{O}$, glucose.
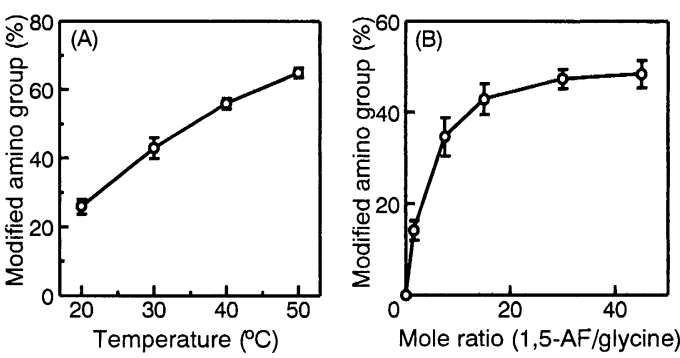

Fig. 3. Modification of glycine with 1,5-AF.

(A) Temperature dependence for the reaction at the molar ratio of 1,5-AF to glycine, $15: 1$. (B) Molar ratio dependence of $1,5-\mathrm{AF}$ to glycine on the reaction at $30^{\circ} \mathrm{C}$ for $48 \mathrm{~h}$.

$30^{\circ} \mathrm{C}$ for $48 \mathrm{~h}$ (Fig. 3B). From these results, we chose the sugar/amino-group ratio of 30 and a reaction temperature of $30^{\circ} \mathrm{C}$ for further studies. When 1,5-AF was incubated as above without lysine, the amount of the sugar was decreased to $50 \%$ after $48 \mathrm{~h}$. This could be one reason why a large excess amount of 1,5-AF was needed for the reaction. The glycosylation with 1,5-AF proceeded in a solid state even under mild conditions, but it did not proceed as well in a diluted buffer solution (data not shown). 1,5-AF exists in a hydrate form in an aqueous solution, but in dimeric forms in non-aqueous solution. ${ }^{16)}$ Thus, it is probable that the different forms of 1,5-AF have different reactivity and products. The analyses of the resulting products remain for as a future study.

\section{Modification of lysozyme.}

Under the above conditions, $35 \%$ of the free 
amino groups in lysozyme were modified after incubation for $144 \mathrm{~h}$ at $30^{\circ} \mathrm{C}$ (Fig. 4). We prepared two lysozyme preparations, of which 10 and $35 \%$ of the free amino groups were abolished (termed as 10- and 35-lysozyme, respectively). These were dissolved in water, and the free 1,5-AF was removed by repeated dialysis against water.

Both preparations showed two bands (14 and 28 $\mathrm{kDa}$ ) on SDS-PAGE (Fig. 5), and one band was found in a control preparation (c-lysozyme) that was treated as above without 1,5-AF. The band width of $14 \mathrm{kDa}$ in 35-lysozyme was broader than the c-lysozyme band, suggesting that the prepara-

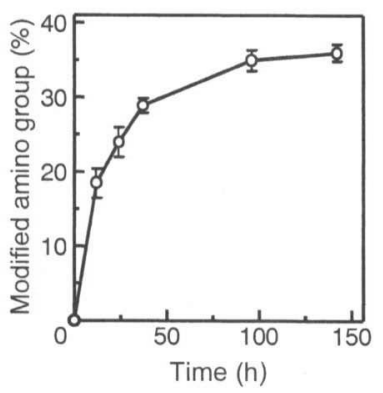

Fig. 4. Modification of lysozyme with 1,5-AF.

The mixture of lysozyme $(1 \mathrm{mg} / \mathrm{mL})$ and $1,5-\mathrm{AF}(2.5$ $\mathrm{mg} / \mathrm{mL})$ in $100 \mathrm{~mm}$ phosphate buffer $(\mathrm{pH} 7.5)$ was lyophilized and incubated at $30^{\circ} \mathrm{C}$ under $7.6 \%$ relative humidity.

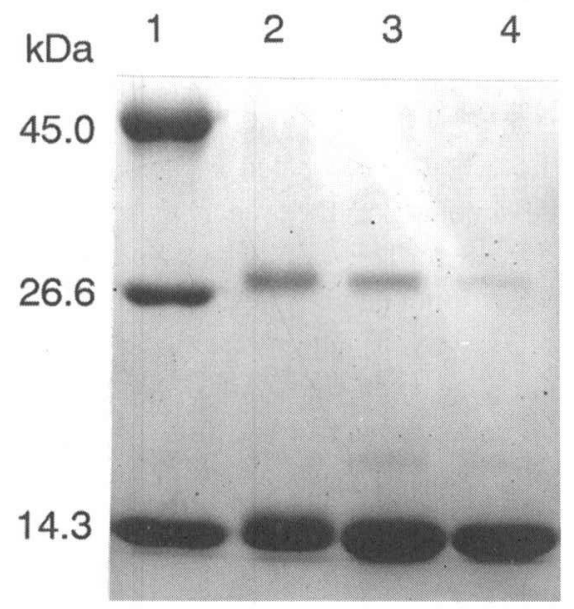

Fig. 5. SDS-PAGE of modified lysozyme.

Proteins were stained by Coomassie Brilliant Blue R250. Lane 1, Mr markers; lanes 2, 3 and 4, 35-, 10-, and clysozyme, respectively. Protein standards: egg albumin $(45.0 \mathrm{kDa})$, triosephosphate isomerase $(26.6 \mathrm{kDa})$, and chicken egg-white lysozyme (14.3 kDa). tion was a mixture of different $M_{\mathrm{r}}$ because of the different extent of glycosylation. The band at the position of $28 \mathrm{kDa}$ in both preparations seemed to be a dimer protein that might emerge with crosslinking. By a quantitative analysis of the each band, the ratios of the amount of 14 to $28 \mathrm{kDa}$ were determined to be $5: 1$ and $3.5: 1$ in regard to 10 - and 35-lysozyme, respectively, showing that the ratio of the amount of $28 \mathrm{kDa}$ increased as the reaction proceeded. Yeboah et al. reported that a polymerization of bovine serum albumin was induced by modification with glucose ${ }^{17)}$ possibly due to the dicarbonic acid which was produced by the oxidation of glucose.

To analyze the molecular weights of the modified lysozyme in detail, 35-lysozyme was analyzed by TOF-MS. The molecular weight of the control lysozyme preparation was 14,265 , and this result certified that no degradation or cross-linking of lysozyme had occurred during incubation in the absence of 1,5-AF. The spectrum of 35-lysozyme showed 3 peaks (Fig. 6, inset), and a main peak around $14 \mathrm{kDa}$ had a very wide distribution that consisted of several peaks. We could find a very small peak at 14,265, whose value showed $M \mathrm{r}$ of a native enzyme, and several small peaks were found at every 144 interval. The most abundant molecular species seemed to be the protein conjugated with 4 sugars (Fig. 6). This number seemed larger than an expected value of 2 or 3 , since lysozyme has 6 lysyl residues and an $\mathrm{N}$-terminal residue, and the extent of modification was $35 \%$. One possibility would be the modification of arginine residues in lysozyme as suggested by Yeboah et al.$^{18)}$ on the occasion of lysozyme modification with glucose. Further experiments will be needed to account clearly for this discrepancy.

To examine the alteration of function upon the modification, the activities of the 35- and clysozyme on glycolchitin were compared. The apparent shift of $\mathrm{pH}$-dependent activity profile of the modified lysozyme could be expected, since the positive charges of the protein surface had been neutralized by conjugation of the neutral sugar. The optimum $\mathrm{pH}$ values of the 35 - and c-lysozyme were 4.5 and 5.0 , respectively. The relative specific activity of 35 -lysozyme was $95 \%$ of the ac- 


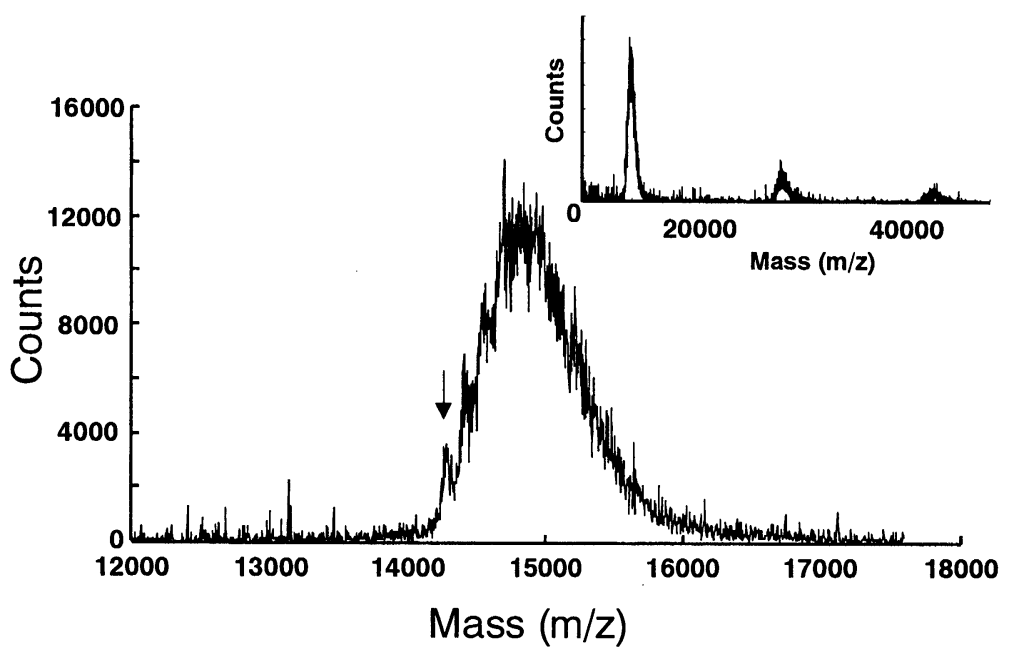

Fig. 6. TOF-MS spectrum of 35-lysozyme.

Arrow indicates the $\mathrm{m} / \mathrm{z}$ value of c-lysozyme. The insert shows the spectrum of the wide range of $\mathrm{m} / \mathrm{z}$.
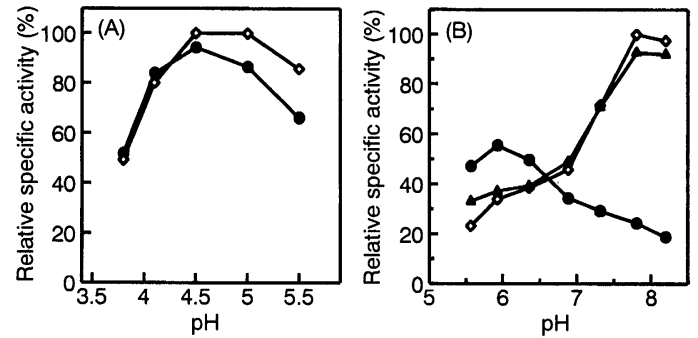

Fig. 7. $\mathrm{pH}$ dependence of the activity of modified lysozyme.

(A) Glycolchitin as a substrate. The pHs were adjusted with acetate buffer (final conc., $50 \mathrm{mM}$ ). The specific activity of c-lysozyme at $\mathrm{pH} 4.5$ was taken as $100 \%$. (B) Freeze dried $M$. lysodeikticus as a substrate. The specific activity of c-lysozyme at $\mathrm{pH} 7.8$ was taken as $100 \%$. The pHs were adjusted with phosphate buffer (final conc., $50 \mathrm{~mm}$ ). 35-lysozyme; $\boldsymbol{\Delta}$, 10-lysozyme; $\diamond$, c-lysozyme.

tivity of c-lysozyme (Fig. 7A) at maximum $\mathrm{pH}$. These results indicated that the glycosylation inflicted almost no damage on the catalytic activity and structure of lysozyme, and suggested that the lysozyme dimer kept its own activity.

Although the enzymatic activity on soluble glycolchitin indicates the catalytic efficiency of the enzyme, the action on the bacterial cell wall is practically important to evaluate the effect of the lysozyme modification. The $\mathrm{pH}$-activity profiles of the control and modified enzymes on lyophilized cells of M. lysodeikticus are shown in Fig. 7B. Although the $\mathrm{pH}$ profiles of $\mathrm{c}$ - and 10-lysozyme were almost the same, that of 35-lysozyme was completely different. The optimum $\mathrm{pH}$ value of 35 -lysozyme was $\mathrm{pH} 6.0$, and the relative activity of 35-lysozyme was $130 \%$ of that of c-lysozyme at this $\mathrm{pH}$. Similar results have been reported on the modification of lysozyme with acetic anhydride ${ }^{19)}$ and monomethoxypolyethylene. ${ }^{20}$ The positive charges on the surface of lysozyme are suggested not to be essential for its catalytic action on $\beta-1,4-$ $N$-acetyl-glucosaminidyl linkage of substrate, but essential for the interaction of the enzyme with the negatively charged cell wall of bacteria. The adsorption of the enzyme to the cell by an electrostatic interaction seems to be important for the cell-lytic activity, and the decrease in this activity might be explained by the disappearance of such forces because of the modification of $\mathrm{NH}_{2}$ residues.

A modification of lysine for alteration of properties of a protein by chemicals often introduces insolubility to a target protein and requires severe conditions for a protein to maintain its physiological activity. The coupling of monomethoxypolyethylene to the $\mathrm{NH}_{2}$ group ${ }^{20)}$ seems advantageous because the reaction proceeds at a low temperature; however, the chemical synthesis of the com- 
pound might be laborious. In consideration of the application of the modified lysozyme in the preservation of acidic foods, the modification by 1,5 anhydro-D-fructose should be advantageous over those modified by chemicals, since the sugar is a natural and soluble material.

The heat stability of the 35- and c-lysozyme were evaluated by the incubation of the enzymes at $75^{\circ} \mathrm{C}$ for $60 \mathrm{~min}$. These reactions were tested at $\mathrm{pH} 5.1$ and 7.8. The lytic activities of heated 35lysozyme decreased to $45 \%(\mathrm{pH} \mathrm{5.1)}$ and $14 \%(\mathrm{pH}$ 7.8) of the values before heating, respectively. When c-lysozyme was heated under the same conditions, the activities decreased to $91 \%$ (pH 5.1) and $55 \%(\mathrm{pH} 7.8)$. These suggested that the modification possibly introduced some distortion of the structure due to the hydrophilic nature of the sugars and/or the disappearance of negative charges.

\section{Modification of wheat proteins with 1,5-AF.}

Twenty five percent and $22 \%$ of amino groups in gliadin and glutenin, respectively, were modified with $1,5-\mathrm{AF}$ by the reactions at $30^{\circ} \mathrm{C}$ for $48 \mathrm{~h}$. The number of modified amino groups in these proteins was less than that of lysozyme possibly due to the insoluble nature of these proteins. In the case of gliadin, the modification brought a $56 \%$ and $70 \%$ increase in the solubility and emulsification ability, respectively, as expected. However, almost the same solubility and emulsification ability as those of native protein were observed when the modified glutenin was tested. Glutenin and gliadin are major proteins in wheat flour and give specific properties such as expansibility of the dough, ${ }^{21)}$ so that the addition of the modified gliadin may give new properties to the mixed wheat flour.

In this study, the availability of $1,5-\mathrm{AF}$ as a modifier of the amino group of food proteins was revealed by the lysozyme and wheat protein modifications in a model experiment. The modification of a protein with 1,5-AF causes the loss of the positive charge of the surface of the target, and the alteration of the physical properties of the modified proteins can be expected. The merits of 1,5$\mathrm{AF}$ as a modifier for food proteins would be that the reaction proceeds under mild conditions and that $1,5-\mathrm{AF}$ is an edible and soluble sugar. The
1,5-AF glycosylation of food proteins may result in improvements in the other characteristics, such as stability and resistance against protease.

\section{REFERENCES}

1) M.A. Baute, R. Baute and G. Deffieux: Fungal enzymic activity degrading 1,4- $\alpha$-D-glucans to $1,5-\mathrm{D}$ anhydrofructose. Phytochemistry, 27, 3401-3403 (1988).

2 ) A. Broberg, L. Kenne and M. Pedersén: Analysis of 1,5-anhydro-D-fructose, microthecin, and 4-deoxyglycero-hexo-2,3-diulose in algae using gas chromatography-mass spectrometry in selected ion monitoring mode. Anal. Biochem., 268, 35-42 (1999).

3 ) S. Kametani, Y. Shiga and H. Akanuma: Hepatic production of 1,5-anhydrofructose and 1,5-anhydroglucitol in rat by the third glycogenolytic pathway. Eur. J. Biochem., 242, 832-838 (1996).

4 ) S. Yu, L. Kenne and M. Pedersen: $\alpha-1,4-G l u c a n$ lyase, a new class of starch/glycogen degrading enzyme. I. Efficient purification and characterization from red seaweeds. Biochim. Biophys. Acta, 1156, 313-320 (1993).

5 ) S. Yu, C. E. Olsen and J. Marcussen: Methods for the assay of 1,5-anhydro-D-fructose and $\alpha$-1,4-glucan lyase.Carbohydr. Res., 305, 73-82 (1998).

6 ) M. Fujisue, K. Yoshinaga, K. Muroya, J. Abe and S. Hizukuri: Preparation and antioxidative activity of 1,5anhydro-D-fructose. J. Appl. Glycosci., 46, 439-444 (1999).

7 ) K. Yoshinaga, M. Fujisue, J. Abe, Y. Takeda and S. Hizukuri: Specific and sensitive determination methods for 1,5-anhydro-D-fructose. J. Appl. Glycosci., 48, 139-142 (2001).

8 ) Y. Kato, T. Aoki, N. Kato, R. Nakamura and T. Matsuda: Modification of ovalbumin with glucose 6phosphate by amino-carbonyl reaction: Improvement of protein heat stability and emulsifying activity. $J$. Agric. Food Chem., 43, 301-305 (1995).

9 ) K. Takahashi, X. F. Lou, Y. Ishii and M. Hattori: Lysozyme-glucose stearic acid monoester conjugate formed through the maillard reaction as an antibacterial emulsifier. J. Agric. Food Chem., 48, 2044-2049 (2000).

10) H. Yamada and T. Imoto: A convenient synthesis of glycolchitin, a substrate of lysozyme. Carbohydr. Res., 92, 160-162 (1981).

11) S. Antes and H. Wieser: Effect of high and low molecular weight glutenin subunits on rheological dough properties and bread making quality of wheat. Cereal Chem., 78, 157-159 (2001).

12) R. Fields: The measurement of amino group in protein 
and peptides. Biochem. J., 124, 581-590 (1971).

13) V. Tropini, J.P. Lens, W.J. Mulder and F. Silvestre: Cross-linking of wheat gluten using a water-soluble carboimide. Cereal Chem., 77, 333-338 (2000).

14) T. Aoki, Y. Hiidome, K. Kitahata, Y. Sugino, H.R. Ibrahim and Y. Kato: Improvement of heat stability and emulsifying activity of ovalbumin by conjugation with glucuronic acid through the Maillard reaction. Food Res. Int., 32, 129-133 (1999).

15) R.M. Cleale, 4 th, T.J. Klopfenstein, R.A. Britton, L. D. Satterlee and S.R. Lowry: Induced non-enzymatic browning of soybean meal. I. Effect of factors controlling non-enzymatic browning on in vitro ammonia release. J. Anim. Sci., 65, 1312-1318 (1987).

16) S.M. Andersen, I. Lundt and J. Marcussen: 1,5Anhydro-D-fructose: stereoselective conversions to 1,5-anhydroalditols and deoxy/amino substituted analogues. J. Carbohydr. Chem., 19, 717-725 (2000).

17) F.K. Yeboah, I. Alli and V.A. Yaylayan: Reactive of D-glucose and D-fructose during glycation of bovine serum albumin. J. Agric. Food Chem., 47, 3164-3172 (1999).

18) F.K. Yeboah, I. Alli, V.A. Yaylayan, Y. Konishi and P. Stefanowicz: Monitoring glycation of lysozyme by electrospray ionization mass spectrometry. J. Agric. Food Chem., 48, 2766-2774 (2000).

19) N. Yamasaki, K. Hayashi and M. Funatsu: Acetylation of lysozyme part I. Mechanism of lysis by lysozyme. Agric. Biol. Chem., 32, 64-68 (1968).

20) Y. Nodake and N. Yamasaki: Some properties of a macromolecular conjugate of lysozyme prepared by modification with a monomethoxypolyethylene glycol derivative. Biosci. Biotechnol. Biochem., 64, 767-774 (2000).

21) W.P. Campbell, C.W. Wrigley, P.J. Cressey and C.R. Slack: Statistical correlation between quality attributes and grain-protein for 71 hexaploid wheats used as breeding parents. Cereal Chem., 64, 293-299 (1987).

(Received October 9, 2001; Accepted November 19, 2001)
新しいアミノ基の修飾剂,

1,5-アンヒドロ-D-フルクトースによる

アミノ酸と蛋白質の修飾

吉永一浩, 藤末真実 ${ }^{1}$, 安部淳一 ${ }^{2}$

竹田靖史 ${ }^{2}$, 檜作 進 $^{3}$

鹿児島大学大学院農学研究科

（890-0065 鹿児島市郡元 1-21-24）

${ }^{1}$ 日本澱粉工業株式会社

（891-0196 鹿巟島市南栄 3-20)

2 鹿児島大学農学部

（890-0065 鹿览島市郡元 1-21-24）

3 神戸女子大学家政学部

（654-8585 神戸市須磨区東須磨青山 2-1）

1,5-アンヒドロ-D-フルクトース (1,5-アンヒドロ-Dアラビノーヘキソ-2-ウロース，1,5-AF)はアミノ基とよ く反応するため, アミノ化合物の修飾剂としての利用 が期待できる.グリシンと $1,5-\mathrm{AF}$ を $50^{\circ} \mathrm{C}, \mathrm{pH} 7.5$ で 反応させた場合の着色は，グルコースやキシロースよ りも大きかった１,5-AFとグリシンの混合物を凍結 乾燥した後, $30^{\circ} \mathrm{C}$ で 48 時間反応させると $45 \%$ のア ミノ基が修飾された。一方，同じ条件のグルコースで は $5 \%$ 以下であった。この1,5-AFによる修飾をリゾ チームに応用した．修飾リゾチームの質量分析から 1,5-AF が分子内に導入されていることが確かめられ た. 修飾リゾチームの最適 $\mathrm{pH}$ は，グリコールキチン を基質とした場合 $\mathrm{pH} 4.5$ で未修飾は $\mathrm{pH} 5.0$ であった。 一方, Micrococcus lysodeikticus の乾燥菌体を基質とし た場合は最適 $\mathrm{pH}$ が修飾により $\mathrm{pH} 7.8$ から 6.0 に変化 した.コムギ蛋白であるグリアジンとグルテニンを同 様に修飾したところ, 修飾グリアジンの乳化性と溶解 性が向上した。 